\title{
A Phase I study of AD5-GUCY2C-PADRE in stage I and II colon cancer patients
}

\author{
Adam Snook ${ }^{1 *}$, Trevor Baybutt ${ }^{1}$ Michael Mastrangelo ${ }^{1}$, Nancy Lewis', Scott Goldstein', Walter Kraft', Yaa Oppong ${ }^{1}$, \\ Terry Hyslop ${ }^{2}$, Ronald Myers' ${ }^{1}$ Vitali Alexeev' ${ }^{1}$ Laurence Eisenlohr', Takami Sato', Scott Waldman \\ From 30th Annual Meeting and Associated Programs of the Society for Immunotherapy of Cancer (SITC 2015) \\ National Harbor, MD, USA. 4-8 November 2015
}

\section{Background}

Ad5-GUCY2C-PADRE is a replication-deficient human type 5 recombinant adenovirus (Ad5) vaccine encoding guanylyl cyclase $\mathrm{C}$ (GUCY2C) fused to the PAn DR Epitope (PADRE). GUCY2C, a paracrine hormone receptor producing the second messenger cyclic GMP (cGMP), is selectively expressed by intestinal epithelial cells and a subset of hypothalamic neurons, but not other tissues. Importantly, GUCY2C is over-expressed in nearly all primary and metastatic human colorectal tumors. Preclinical studies in mice demonstrated selective tolerance of GUCY2C-specific CD4+ T cells, but not CD8+ T or $B$ cells, necessitating inclusion of the exogenous CD4+ $\mathrm{T}$ helper cell epitope PADRE to maximize GUCY2Cspecific CD8+ T cell and antibody responses and antitumor efficacy, without autoimmunity.

\section{Patients and methods}

This is an open-label, single arm "proof-of-concept" study evaluating a single dose level of Ad5-GUCY2C-PADRE as a vaccine for surgically-treated, node-negative colon cancer subjects (NCT01972737). Patients received a single intramuscular administration of $10^{11}$ Ad5-GUCY2CPADRE viral particles. Safety and immunomonitoring where examined at 30, 90 and 180 days following vaccination. Primary objectives were to determine the safety, tolerability and toxicity of Ad5-GUCY2C-PADRE and to determine whether Ad5-GUCY2C-PADRE induces GUCY2C-specific immune responses. The study employed a joint efficacy-toxicity design and included stopping rules for either efficacy or toxicity. Results here were obtained during the planned interim analysis following accrual of 10 subjects.

\section{Results}

The vaccine was well tolerated, producing only mild adverse events (AEs). Short-lived injection site pain/swelling, body aches and chills were the most commonly observed AEs and occurred in 30-40\% of subjects. GUCY2C-specific antibody and T-cell responses were observed in a subset of subjects. Consistent with preclinical mouse data, T-cell responses were composed of CD8+, but not CD4+, $\mathrm{T}$ cells. Importantly, GUCY2C-specific responses occurred only in subjects with low Ad5 neutralizing antibody (NAb) titers at the time of vaccination, suggesting that pre-existing Ad5 immunity limits Ad5-GUCY2C-PADRE immunogenicity.

\section{Conclusions}

Interim analysis of 10 subjects receiving Ad5-GUCY2CPADRE demonstrates proof-of-concept that GUCY2C is immunogenic in humans and that GUCY2C-directed vaccination is safe. Moreover, the presence of GUCY2Cspecific antibody and CD8+ T-cell, but not CD4+ T-cell, responses is consistent with selective $\mathrm{CD} 4+\mathrm{T}$-cell tolerance observed in mouse models. These data establish GUCY2C as a safe and immunogenic target for immunotherapy in cancer patients.

\section{Trial registration}

ClincialTrials.gov identifier NCT01972737.

\author{
Authors' details \\ ${ }^{1}$ Thomas Jefferson University, Philadelphia, PA, USA. ²Duke University, \\ Durham, NC, USA.
}

${ }^{1}$ Thomas Jefferson University, Philadelphia, PA, USA

Full list of author information is available at the end of the article 
doi:10.1186/2051-1426-3-S2-P450

Cite this article as: Snook et al: A Phase I study of AD5-GUCY2C-PADRE

in stage I and II colon cancer patients. Journal for ImmunoTherapy of

Cancer 2015 3(Suppl 2):P450.

Submit your next manuscript to BioMed Central and take full advantage of:

- Convenient online submission

- Thorough peer review

- No space constraints or color figure charges

- Immediate publication on acceptance

- Inclusion in PubMed, CAS, Scopus and Google Scholar

- Research which is freely available for redistribution

Submit your manuscript at www.biomedcentral.com/submit 